ISSN 1110-0230

\title{
Using Agrowastes in Mushroom Production and Compost Recycling to Control Cucumber Anthracnose Caused by Colletotrichum orbiculare
}

\section{Khalil, A.A. ${ }^{1}$ and Abdel-Kawi, K.A. ${ }^{2}$}

1- Plant Pathology Research Institute, Agricultural Research Center, Giza, Egypt.

2- Soils, Water and Environment Research Institute, Agricultural Research Center, Giza, Egypt.

$F^{\text {our types of grains; sorghum, rice, maize and wheat were evaluated }}$ as carriers for spawn preparation for mushroom production in winter of 2018. The most suitable spawns used were on rice or wheat grains. Two strains of the Basidio-fungus Pleurotus were cultivated on rice straw separately at spawn ratio 5\%. Chemical analysis of fruiting bodies showed that $P$. sajor-caju recorded 15.1, 7.8, 53.7, 13.6 and $6.49 \%$ for crude protein, fat, carbohydrate, fiber and ash, respectively. While chemical analysis of $P$. florida fruiting bodies recorded 13.9, $5.6,57.5,11.3$ and $9.87 \%$, respectively for the same components. On the other hand, chemical analysis of rice straw was carried out before and after cultivation of spent mushroom substrate (SMS) which was leftover as wastes from mushroom production through the entire year. SMS was used in greenhouse for cucumber plantation as an organic matter as a soil supplement and cucumber diseases control. Ascending order of inhibition was noticed with increasing filtrate concentration. Pleurotus florida inhibited mycelia growth of $C$. orbiculare at 42.2, $50.0,75.6$ and $78.9 \%$ when media were treated with 25, 50, 75 and $100 \%$ concentration, respectively. Extract of $P$. florida gave a maximum effect of $78.9 \%$ inhibition when compared to the other strain which gave $70.0 \%$. All treatments used in this experiment seemed to promote germination percentage from $35 \%$ (control $2=$ soil $+C$. orbiculare) to $92 \%$ resulted from $100 \%$ SMS in case of $P$. florida SMS compost. Although values of germination percentage were lower in case of SMS produced through mushroom production using the strain P. sajor-caju, it promoted from 40 (control 2) to $93 \%$ (100\% SMS). Relative effects of SMS were calculated between each two treatments having the same amount of SMS. The maximum relative increment recorded in case of $\mathrm{T} 7$ with $P$. florida SMS which calculate +163 in seed germination, followed by $\mathrm{T} 7$ with $P$. sajor-caju $(+132.5)$. Simultaneously, disease incidence was negatively affected with SMS treatments. The least disease incidence was recorded with T7 with $P$. sajor-caju which recorded negative value that could be explained by saving weak seeds from decline with boost of some antimicrobial substance.

Keywords: Cucumber, Mushroom, Pleurotus florida, Anthracnose, Colletotrichum orbiculare, Agrowastes, Production, 
Human nutrition, environment and plant disease control are three major goals for all agriculturists including plant pathologists who play distinguished role to achieve the three goals through applying different strategies.

Better human nutrition could be achieved by mushroom cultivation which is considered the golden key to increase protein production. Khan et al. (2012) stated that mushrooms with their pleasant flavor, texture and high productivity per unit area have been recognized as an exceptional food source of alleviate malnutrition in developing countries. Stanley et al. (2011) reported high nutritional values of oyster mushroom with protein $(25-50 \%)$, fat (2-5\%), sugar (17-47\%), minerals (sodium, calcium, potassium and phosphorus) of about 8-12\%. Edible mushrooms are also rich in vitamins as niacin, riboflavin, vitamin $\mathrm{D}, \mathrm{C}, \mathrm{B}_{1}, \mathrm{~B}_{5}$ and $\mathrm{B}_{6}$ (Syed et al., 2009). Mushroom is one of the most charming creatures capable to grow on agricultural wastes enabling us to obtain beneficial substrate materials at low prices or even for free.

Environmentally, a tremendous amount of agricultural residues (wastes) especially remaining of rice crop is generated seasonally in Egypt and presents continues problem confronting the country government. Mushroom production conserves our environment through sustainable recycling process of agro-wastes through converting it to usable bio-fertilizer (Khan et al., 2012). Rice straw was extensively studied for the production of P. ostreatus, P. sajor-caju and P. florida, that showed rapid growth and good yield (Jwanny et al., 1995; Randhir et al., 1999 and Singh and Grienseven, 2000). Sathyaprabha et al. (2011) studied the growing of Pleurotus pulmonarius in hot climate weather environment. Frutification was faster on rice straw substrate when compared to other materials. Also, rice straw substrates showed the highest yield of Pleurotus platypus (520g) in first harvest and totally $(1050 \mathrm{~g})$, when compared to Pleurotus eous which showed only $485 \mathrm{~g}$ in first harvest and totally $(945 \mathrm{~g})$ but the paddy straw substrate were suitable to cultivate these two edible mushroom species. While, Ravinder et al. (2012) used wheat straw, maize cob straw and lentil straw alone or wheat straw in combination with maize cob straw and lentil straw in 1:2, 1:1 and 2:1 ratios and organic supplements viz., wheat bran, rice bran, corn meal, soybean meal for oyster mushroom (Pleurotus spp.) production that gave the highest yield of $P$. sajor-caju followed by $P$. florida with 57.3 and $55.0 \%$ (BE\%), respectively.

Regarding plant disease control, many researchers proved that during mushroom cultivation process, many by-products were extracted which act as anti-microbial agents. Zhanxi and Zhanahua (1997) exhibited various therapeutic activities of extracts or isolated compounds in fermentation broth, and mycelia and fruiting bodies of Pleurotus spp. In particular polysaccharides appear to be antitumor and immune-enhancing substances, besides possessing other beneficial activities. Moreover, Gregori et al. (2007) explained other major values of Pleurotus species which commonly possess number of medicinal properties such as antitumor,

Egypt. J. Phytopathol., Vol. 47, No. 2 (2019) 
immunomodulatory, antiviral, antihypertensive, antiplatelet-aggregating, antihyperglycaemic and antimicrobial activities. It is widely known that systemic acquired resistance (SAR) can protect or even control a broad spectrum of plant pathogens, including fungi, bacteria and viruses (Vallad and Goodman, 2004 and Conrath, 2006). Therefore, fresh spent mushroom substrate (SMS) that still impregnated with mushroom mycelia could be a viable and abundant source of elicitors for SAR.

Anthracnose caused by the fungus Colletotrichum orbiculare (Berk. \& Mont.) Arx syn. of $C$. lagenarium, the asexual (anamorph) stage of the pathogen, while its sexual stage (telemorph) is Glomerella lagenarium (Walker et al., 1991) which is considered as a destructive disease of cucurbits. All aboveground plant parts are affected. Significant damage can occur on one of the most fresh edible crops in Egypt; cucumber. Colletotrichum orbiculare can be associated with seed and infected crop debris. Disease development is favored by warm, humid weather.

Current work aimed to determine the best local waste substrate that could maximize growth and yield performance of oyster mushrooms $P$. florida and $P$. sajor-caju. Consequently, evaluation the efficiency of the spent mushroom substrate (SMS) in protecting or controlling cucumber anthracnose disease caused by Colletotrichum orbiculare and finally, encourage researchers to think scientifically on preserve clean and safe environment.

\section{Materials and Methods}

Microorganisms:

Two strains of Pleurotus namely, P. florida (NRRL 3526) and P. sajor-caju (UPVP 503) were supplied from the Culture Collection maintained in Microbiology Res. Dept., Soils \& Waters and Environment Res. Inst., ARC, Egypt. Strains were chosen for their good growth characteristics and stability and used in this study. Routinely, were maintained on potato dextrose agar ( PDA) slants fortified with $0.3 \%$ yeast extract, incubated at $25 \pm 2{ }^{\circ} \mathrm{C}$ for $48-72 \mathrm{~h}$, then stored at $4^{\circ} \mathrm{C}$ (Garcha, 1981).

While for the pathogen Colletotrichum orbiculare, samples of apparently diseased cucumber plants with anthracnose symptoms were collected from greenhouses located in Giza, Qalyubia and Behiera governorates, Egypt. Samples were freshly delivered to Seed Pathology Res. Dept., Plant Pathol. Res. Inst., ARC, washed under running tap water and cut into approximately $1-2 \mathrm{~cm}$ pieces, surface sterilized in $3 \% \mathrm{NaOCl}$ for $2 \mathrm{~min}$., rinsed several times with sterile distilled water for one min each and blotted on sterilized filter paper. Pieces were then placed on potato dextrose agar (PDA), incubated at $25 \pm 2^{\circ} \mathrm{C}$ for three days. Pure cultures were derived by sub-culturing the margins of colonies on PDA and incubated for five more days under similar conditions. 
Developed fruiting bodies were then picked off using a fine sterile glass needle and a stereoscopic microscope to transfer it into PDA slants and incubated for 10 days. Eight Petri dishes containing PDA medium were inoculated with single conidia and incubated at $20^{\circ} \mathrm{C} \pm 2$ for two weeks under $12 \mathrm{~h}$ of alternating cycles of near ultraviolet light (NUV) and complete darkness. Colony features; mycelium characteristics, reproductive structures and overall colony appearance were described.

Identification of the obtained isolates was kindly consulted by Prof. Dr. A.A. ElWakil, Seed Pathol. Res. Dept. Confirmation was carried out according the description of Domasch et al. (1980). Culture was maintained on PDA slants and refrigerated at $4^{\circ} \mathrm{C}$ until use.

\section{Preparation of grain spawn:}

Wheat, sorghum, maize and rice seeds were cleaned from debris and soaked in water over night. Seeds were washed then boiled in water (at least 10-15 min). After cooling, seeds were transferred to a round bottles (occupy $2 / 3$ of its volume) and mixed with both of $2 \% \mathrm{CaCO}_{3}$ and $1 \% \mathrm{CaSO}_{4}-(\mathrm{w} / \mathrm{w})$. Bottles were then sterilized for 1 hour at $121^{\circ} \mathrm{C}$. After cooling, the sterilized bottles were inoculated with 6 days old culture mycelia pieces $(2-3 \mathrm{~cm})$ from the above mentioned tested strains. The inoculated bottles were incubated at $25^{\circ} \mathrm{C}$ for 21 days. The grain spawn master was used to inoculate agro-residues substrate for production the fruiting bodies (Garcha, 1981).

\section{Preparation of agro-wastes:}

Three agricultural wastes of rice straw, wheat straw and cotton stalks were used. The agro-residues were chopped into $5-10 \mathrm{~cm}$ bits and soaked overnight in water. Hot water treatment was accomplished by dipping the agro-residues separately in boiling water for 2 hours and excess water was drained. After cooling to ambient temperature, the substrate was transferred into polyethylene bags $(30 \times 75 \mathrm{~cm} ; 4.5 \mathrm{~kg}$ wet 1.5 dry substrate/bags). Spawning was carried out using $5 \%$ spawn on rice straw, maize stalks and cotton stalks (Khana and Garcha, 1982). Each treatment was replicated three times then bags were tied and incubated at $25 \pm 2^{\circ} \mathrm{C}$ for 15 days till spawn running. Then, the bags were opened when substrate was fully permeated by the fungal mycelium. Adequate relative humidity $(80 \%)$ was maintained through the experiment by occasional spraying water twice on day and night times.

\section{Harvesting:}

Mushroom was harvested upon reaching maturity. At this stage the fruiting bodies were picked up. No selective cutting was practiced, the first cutting is referred to as $1^{\text {st }}$ flush. The flushes were taken at intervals of 7 days according to Mueller and Gawley (1983).

Egypt. J. Phytopathol., Vol. 47, No. 2 (2019) 
Chemical determinations:

- Biological efficiency percentage (BE\%) is given on the basis of the ratio of yield (fresh weight) to the dry substrate weight.

$$
\mathrm{BE} \%=\mathrm{F} . \mathrm{W} / \mathrm{D} . \mathrm{Wx} 100 \text {. }
$$

- Moisture content, ash, crude protein, crude fiber and lipids were determined according to Horwitz (1980).

- Total carbohydrates in the edible mushrooms were estimated by the phenolsulphuric acid method (Dubois et al., 1956).

- Total hydrolysable carbohydrates were determined as previously described by Montgomery (1961).

- Cellulose and hemicelluloses were determined according to Chahal et al. (1979). Also, lignin was determined according to the method of Tanaka et al. (1985).

- Marco and micro-elements (Fe, $\mathrm{Zn}, \mathrm{Cu}, \mathrm{Ca}, \mathrm{P}, \mathrm{Na}, \mathrm{K}, \mathrm{Mg}$ and $\mathrm{Mn}$ ) were determined according to the methods described by (Anon., 1998).

- Organic carbon was determined according to Black et al. (1965). Organic matter was calculated by multiplying organic carbon content of sample x 1.7241 (conversion factor).

Disease assessment:

In current investigation, two main parameters of disease assessment were conducted as direct indications of cultivating vegetables in pure SMS or in certain amounts of it as an amendments added to soil as compost. Direct evaluation was done in vitro on the anthracnose pathogen of cucumber $C$. orbiculare. Moreover, a greenhouse experiment was carried out.

Evaluation of mushroom extract on C. orbiculare mycelial growth in vitro:

Effect of culture extracts of the two mushroom strains were tested on mycelial growth of $C$. orbiculare using PDA plates. Crude filtrated extract was considered as $100 \%$ conc. A portion of crude extract was used to prepare three more concentrations of 25,50 and $75 \%$ by adding known volumes of distilled sterilized water. Two hundred microliters of each concentration were used to flood the surface of a $9 \mathrm{~cm}$ diam. PDA dish to form a thin layer. Extract was replaced with $200 \mu \mathrm{l}$ of sterilized distilled water as control. Seven-days-old disks of $5 \mathrm{~mm}$ diam. of $C$. orbicualre were placed in the center of the PDA dishes containing extracts. Three replicates of each treatment were used. Dishes were then incubated at $25 \pm 2^{\circ} \mathrm{C}$ until control treatment was completely covered with pathogen mycelia. Inhibition percentage was calculated as follows:

$$
\text { Inhibition }(\%)=\frac{\text { Diam. of control - diam. of treatment }}{\text { Diam. of control }} \times 100
$$

Evaluation of the two mushroom strains on C. orbiculare under greenhouse conditions:

Soil mixture used consisted of sand and peat in the ratio of 2:1 respectively, and steam treated at $100^{\circ} \mathrm{C}$ for $1.5 \mathrm{~h}$. Sterilized pots of $30-\mathrm{cm}$ diam. containing sterilized 
soil were infested with $0.4 \%$ (w:w) of 15-days old medium composed of fungal pathogen mixed with sand and sorghum, then watered every two days for a week to assist pathogen establishment. Un-infested soil was used as control. Each pot was watered and covered with a polyethylene bag over two days to help fungal establishment and spread. Surface sterilized seeds were washed four times in sterilized water then dried between two sterilized filter papers. Ten seeds of cucumber Balady $\mathrm{cv}$. were sown per pot and 3 replicates were used per each treatment. Percentage of germination was recorded after 15 days, while disease incidence was recorded and calculated after 45 days from sowing using the following formula:

$$
\begin{aligned}
& \text { Germination }(\%)=\frac{\text { Number of germinated seeds }}{\text { Total number of planted seeds }} \times 100 \\
& \text { Disease incidence }(\%)=\frac{\text { Number of diseased seedlings }}{\text { Total number of seedlings }} \times 100
\end{aligned}
$$

Treatments used

There were nine treatments in this experiment and each treatment was replicated 3 times. Treatments were defined according to the different levels of spent mushroom substrate (SMS) compost as basal application as follows:

$$
\begin{aligned}
& \mathbf{T 1}=\text { soil }+25 \% \text { SMS } \\
& \mathbf{T 2}=\text { soil }+25 \% \text { SMS }+ \text { C. orbiculare } \\
& \text { T3 }=\text { soil }+50 \% \text { SMS } \\
& \text { T4 }=\text { soil }+50 \% \text { SMS }+ \text { C. orbiculare } \\
& \text { T5 }=\text { soil }+75 \% \text { SMS } \\
& \text { T6 }=\text { soil }+75 \% \text { SMS }+ \text { C. orbiculare } \\
& \text { T7 }=100 \% \text { SMS } \\
& \text { T8 }=\text { soil }+ \text { C. orbiculare }(\text { control } 2) \\
& \text { T9 }=\text { soil only }(\text { control } 1) .
\end{aligned}
$$

\section{Results and Discussion}

Data in Table (1) show that wheat and rice grains were suitable substrate (carriers) for growing mushroom as they gave the highest yield of mycelia for both tested strains, $P$. florida and $P$. sajor-caju when compared with other tested grain (sorghum and maize). The later ones showed longer times for completing mycelia formation. The grains of rice and wheat gave remarkably the lowest time (9 and 10 days), respectively. These results are in agreement with the findings of Sathyaprabha et al. (2011) who came to the same conclusion when cultivated $P$. eous and $P$. pulmonarius on different agricultural waste substances.

Egypt. J. Phytopathol., Vol. 47, No. 2 (2019) 
Table (1): Effect of different types of grains used in spawn preparation for Pleurotus spp.

\begin{tabular}{|c|c|c|}
\hline \multirow{2}{*}{ Pleurotus spp. (Ps) } & \multicolumn{2}{|c|}{ Treatments } \\
\cline { 2 - 3 } & Types of grains (Tg) & $\begin{array}{c}\text { Full mycelial formation } \\
\text { (days) }\end{array}$ \\
\hline \multirow{3}{*}{ P. florida } & wheat & 10 \\
& sorghum & 12 \\
& maize & 13 \\
& rice & 10 \\
\hline \multirow{2}{*}{ P. sajor-caju } & wheat & 9 \\
& sorghum & 11 \\
& maize & 9 \\
\hline
\end{tabular}

Evaluation of some crop residues

Three types of agricultural crops residues, i.e. rice straw, wheat straw and cotton stalks were used in this study. Data in Table (2) show that holocellulose was the most prevalent amount representing 65.2, 60.35 and 56.9\% for wheat straw, cotton stalks and rice straw respectively. Data also revealed that cotton stalks contained crude fiber $39.77 \%$, followed by rice straw contained crude fiber $35.15 \%$ and followed by wheat straw, $32.25 \%$. Cellulose content was found to be $34.85,32.52$ and $30.18 \%$ for wheat straw, cotton stalks and rice straw, respectively. Whereas hemicellulose contents of cotton stalks, wheat straw and rice straw were $27.90 \%$ and $24.85 \%$ and $22.82 \%$, respectively. The hemicellulose content of wheat straw was in agreement with the findings of Lin et al. (1985) and Tanaka et al. (1985). Concerning lignin content, cotton stalks were found to contain higher content of lignin (13.22\%), wheat straw (11.10\%) followed by rice straw (9.75\%). Regarding crude protein contents, data indicated that the protein content were 2.88, 2.56 and $1.81 \%$ for cotton stalks, wheat straw and rice straw, respectively. With respect to ash content, data indicated that rice straw contained high ash content $(15.45 \%)$ and that may be due to its high content of silicon. On the other hand, wheat straw contained moderate content of ash (8.53\%). Most crop residues contain 30-40\% cellulose, 1217\% hemicellulose, 3-13\% lignin and 3.7-7.2\% crude protein (Chahal, 1991).

Data in Table (3) show the mineral content of the tested agricultural crop residues (rice straw, wheat straw and cotton stalks). The chemical analysis revealed that rice straw contains high amount of calcium $(1628 \mathrm{mg} / 100 \mathrm{gm}$ dry matter) compared to wheat straw $(815 \mathrm{mg} / 100 \mathrm{~g}$ dry matter) and cotton stalks $457 \mathrm{mg} / 100$ dry matter). Regarding to phosphorus content, both wheat straw and rice straw have the same content, being 388 and $358 \mathrm{mg} / 100$ dry matter and sodium content, being 139 and $120 \mathrm{mg} / 100$ dry matter for rice straw and wheat straw, respectively, while sodium content in cotton stalks reached $945 \mathrm{mg} / 100 \mathrm{~g}$ dry matter. Potassium content of the tested agro-residues was 1075 and $1020 \mathrm{mg} / 100 \mathrm{~g}$ dry matter for cotton stalks 
and wheat straw, respectively, while potassium content reached $838 \mathrm{mg} / 100 \mathrm{~g}$ dry matter. Moreover, residues were found to contain adequate amount of $\mathrm{Mn}, \mathrm{Fe}, \mathrm{Zn}$, $\mathrm{Cu}$ and $\mathrm{Mg}$. The latter element was found in high amount. Whereas, it was found to be 3506,2375 and $1531 \mathrm{mg} / 100 \mathrm{~g}$ dry matter in rice straw, wheat straw and cotton stalks, respectively. Different agro-wastes were differed when chemically analyzed by Abdel-Kawi (1989).

Table (2): Chemical composition of some crop residues used in cultivation of Pleurotus spp.

\begin{tabular}{|c|c|c|c|}
\hline \multirow{3}{*}{ Chemical composition } & \multicolumn{3}{|c|}{ Agricultural crop residues } \\
\hline & Rice straw & Wheat straw & Cotton stalk \\
\hline & \multicolumn{3}{|c|}{$\mathrm{g} / 100$ gram dried matter $(\%)$} \\
\hline Total hydrolyzable carbohydrate & 32.62 & 36.33 & 25.72 \\
\hline Nitrogen & 0.29 & 0.41 & $0 . .446$ \\
\hline Crude protein & 1.81 & 2.56 & 2.88 \\
\hline Crude fat & 1.30 & 0.70 & 0.91 \\
\hline Crude fibers & 35.15 & 32.25 & 39.77 \\
\hline Holocellulose & 56.9 & 65.2 & 60.35 \\
\hline Hemicellulose & 22.82 & 24.85 & 27.9 \\
\hline Cellulose & 30.18 & 34.85 & 32.52 \\
\hline Lignin & 9.75 & 11.1 & 1.22 \\
\hline Ash & 15.45 & 8.5 & 6.1 \\
\hline
\end{tabular}

Table (3): Mineral content of agriculture crop residues used in cultivation of Pleurotus spp.

\begin{tabular}{|c|c|c|c|c|c|c|c|c|c|}
\hline \multirow{3}{*}{ Crop residues } & \multicolumn{10}{|c|}{ Mineral contents } \\
\cline { 2 - 11 } & \multicolumn{1}{|c|}{$\mathrm{mg} / 100 \mathrm{~g}$ dry matter } & \multicolumn{3}{|c|}{$\mu \mathrm{g} / \mathrm{g}$ dry matter } \\
\cline { 2 - 11 } & $\mathrm{Ca}$ & $\mathrm{Na}$ & $\mathrm{P}$ & $\mathrm{K}$ & $\mathrm{Mg}$ & $\mathrm{Mn}$ & $\mathrm{Fe}$ & $\mathrm{Zn}$ & $\mathrm{Cu}$ \\
\hline Rice straw & 1628 & 139 & 358 & 838 & 3506 & 45.75 & 298 & 47.5 & 106 \\
\hline Wheat straw & 810 & 120 & 388 & 1020 & 2375 & 34.34 & 520 & 28.96 & 23.2 \\
\hline Cotton stalks & 457 & 945 & 279 & 1075 & 1531 & 22.62 & 187 & 20.3 & 8.3 \\
\hline
\end{tabular}

Comparative study on the chemical composition of $P$. florida and P. sajor-caju was carried out. It is shown from Table (4) that the dry matter was lower in $P$. florida $(9.1 \%)$ than in P. sajor-caju (10.2\%). Regardless the values obtained in current results, there was an agreement with those reported by Kalberer and Kunsch (1974) and Rai et al. (1988). These authors stated that environmental factors like temperature, humidity, substrate, age of fruit body and post-harvest storage before analysis affect the composition of mushrooms.

The protein content was slightly higher in $P$. sajor-caju $(15.1 \%)$ than in $P$. florida (13.9\%). Previous investigators recorded different results for instance Rai $e t$ al. (1988) recorded similar results, while much higher values were reported by Egypt. J. Phytopathol., Vol. 47, No. 2 (2019) 
Khanna and Garcha (1982). On the other hand, protein content in Pleurotus species was found to be much higher than in common vegetables which ranges from $7.6 \%$ in potato to $18.4 \%$ in cabbage but lower than hen's egg and goat meat which containe 50.6 and 83\%, respectively (Arkroyed 1966 and Bano 1976). Thus the nutritional value of sporophores of $P$. sajor-caju and $P$. florida can be considered as intermediate between vegetable and egg and meat protein (Sivaprakasam, 1983).

Carbohydrate was found to be a major constituent in Pleurotus species (Bano and Rajarathnam, 1982). The values obtained in the present study were 57.5 and $53.7 \%$ for P. florida and P. sajor-caju, respectively on a dry weight basis. Similar, or slightly higher or lower values were reported for these species by several investigators (Bano et al., 1981; Bano and Rajarathnam 1982; Rai et al., 1988). An average, Pleurotus species contained $2.85 \%$ fat (Bano and Rajarathnam, 1982). Higher fat contents were recorded in current study for the two species, although $P$. sajor-caju showed higher fat value than P. florida and this was also previously reported by Rai et al. (1988).

Fiber content was 13.60 and $11.30 \%$ in $P$. sajor-caju and $P$. florida, respectively. These values were within the figures reported by other researchers (Bano et al., 1981 and Rai et al., 1988). The same authors recorded 9.87 and $6.49 \%$ ash content for $P$. florida and $P$. sajor-caju, respectively. The present results showed values within the figures reported by other researchers.

Table (4): Proximate composition of P. florida and P. sajor-caju*.

\begin{tabular}{|c|c|c|c|c|c|c|c|}
\hline Species & 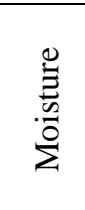 & $\begin{array}{l}\bar{\Xi} \\
\stackrel{\Xi}{\Xi} \\
\Xi \\
\vec{\Xi} \\
\overrightarrow{0}\end{array}$ & 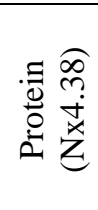 & 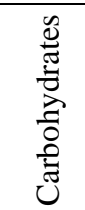 & $\overrightarrow{\widetilde{I}}$ & $\frac{\overline{\mathrm{D}}}{\overline{\overrightarrow{1}}}$ & 专 \\
\hline P. florida & 90.9 & 9.1 & 13.9 & 57.5 & 5.6 & 11.3 & 9.87 \\
\hline P. sajor-caju & 89.8 & 10.2 & 15.7 & 53.7 & 7.8 & 13.6 & 6.49 \\
\hline
\end{tabular}

* All data refer to $\mathrm{g} / 100 \mathrm{~g}$ dry weight basis

Disease assessment:

Although current results concentrated on certain parameters that evaluate anthracnose assessment, they all went in the same trend. Different materials resulted from the production process of edible mushrooms $P$. florida or $P$. sajor-caju, both SMS (compost) or extract were found to suppress the target pathogen $C$. orbiculare. The following results indicated positive effects on cucumber anthracnose.

Isolation and morphological characterization

One isolate of Colletotrichum sp. was isolated from diseased cantaloupe plant parts using PDA medium. Colonies are dark grey to black, with paler margin (Fig. 1:a). Sclerotia abundant, acervuli single or in groups, setae are numerous blackish 
brown to black on color, longer than the conidial mass (Fig. 1:b). One cell hyaline conidia formed in salmon pink masses straight or slightly curved pointed in both ends, $10-15$ x 4.5-6 $\mu$ (Fig.1 :c).
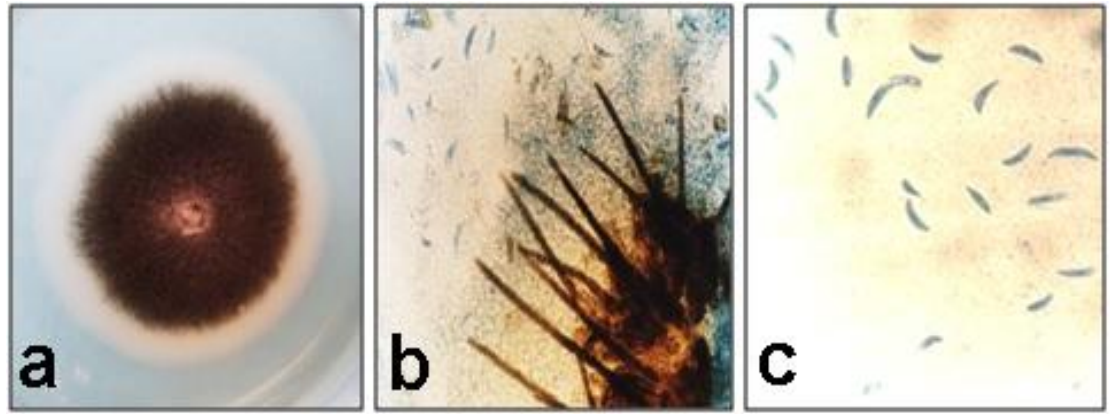

Fig. (1): Characters of $C$. orbiculare:

a: dark grey culture on PDA with paler margins.

b: a portion of mature acervulus with numerous brown blackish setae longer than the conidial mass $(200 \mathrm{x})$.

c: one hyaline cell conidia in salmon pink masses, straight or slightly curved pointed in both ends $(750 \mathrm{x})$.

Typical anthracnose symptoms in some cantaloupe fields grown under sprinkling irrigation were observed for the first time in Egypt. Isolation and purification from the collected diseased plants were carried out and the isolated fungus was morphologically identified as $C$. orbiculare according to El-Wakil and El-Zefzaf (2001).

Many workers in the field of taxonomy concluded that morphological characters alone were not reliable criteria for Colletotrichum identification and have failed to resolve the phylogenetic relationships among the species (Weir et al., 2012; Chen et al., 2015 and Sangpueak et al., 2017). Khalil, et al. (2018) stated that advanced technologies such as polymerase chain reaction (PCR) besides morphological characters in identifying members of the genus Colletotrichum has become necessary.

Effect of mushroom extract on C. orbiculare mycelial growth in vitro:

Results tabulated in Table (5) indicate that extracts of both strains gave positive inhibition on mycelium growth of $C$. orbiculare. Ascending order of inhibition was noticed with increasing filtrate concentration. Pleurotus florida inhibited mycelia growth of $C$. orbiculare at $42.2,50.0,75.6$ and $78.9 \%$ when media were treated with $25,50,75$ and $100 \%$ concentration, respectively. Extract of $P$. folrida gave maximum effect than the other strain when recorded 78.9 comparing $70.0 \%$ inhibition, respectively. Obtained results in current study supported those of

Egypt. J. Phytopathol., Vol. 47, No. 2 (2019) 
(Gregori et al., 2007) who stated that various Pleurotus species possess a number of medicinal properties such as, antitumor, immunomodulatory, antivirial, antihypertensive, antiplatelet- aggregating, antihyperglycaemic and antimicrobial activities. On the other side, Chen and Huang (2011) stated that 13 out of 27 extracts of edible mushroom strains were able to suppress mycelial growth of 7 different plant pathogens belong to several fungal families with a maximum inhibition of $37.3 \%$. They also concluded that the antimicrobial effects of the culture filtrates depended on the strain and species of mushroom and the species of microorganism. Surprisingly, Estrella et al. (2012) recorded inhibition of the growth of Fusarium oxysporum f.sp. melonis when sterilized compost extract was applied at a dose lower than $10 \%$ while higher concentrations were not effective. They assumed that was because of toxic substances and nutrient content ratio in the culture media. Moreover, they concluded that the suppressive effect of compost is due to a combination of biotic and abiotic factors.

Table (5): Effects of the culture filtrates of $\boldsymbol{P}$. florida and $\boldsymbol{P}$. sajor-caju edible mushrooms on mycelial growth of $C$. orbiculare.

\begin{tabular}{|c|c|c|c|c|c|c|c|c|c|}
\hline \multirow{3}{*}{$\begin{array}{l}\text { Fungal } \\
\text { species }\end{array}$} & \multicolumn{9}{|c|}{ Extract concentration $(\%)$} \\
\hline & \multirow{2}{*}{$\begin{array}{l}\text { Cont. } \\
(\mathrm{mm})\end{array}$} & \multicolumn{2}{|c|}{25} & \multicolumn{2}{|c|}{50} & \multicolumn{2}{|c|}{75} & \multicolumn{2}{|c|}{100} \\
\hline & & $\begin{array}{l}\text { Diam. } \\
(\mathrm{mm})\end{array}$ & $\begin{array}{c}\text { Inhib. } \\
\%\end{array}$ & $\begin{array}{l}\text { Diam. } \\
(\mathrm{mm})\end{array}$ & $\begin{array}{c}\text { Inhib. } \\
\%\end{array}$ & $\begin{array}{l}\text { Diam. } \\
(\mathrm{mm})\end{array}$ & $\begin{array}{c}\text { Inhib. } \\
\%\end{array}$ & $\begin{array}{l}\text { Diam. } \\
(\mathrm{mm})\end{array}$ & $\begin{array}{c}\text { Inhib. } \\
\%\end{array}$ \\
\hline P. florida & 90.0 & 52 & 42.2 & 45 & 50.0 & 22 & 75.6 & 19 & 78.9 \\
\hline P. sajor-caju & 90.0 & 56 & 37.8 & 44 & 51.1 & 32 & 64.4 & 27 & 70.0 \\
\hline
\end{tabular}

Effect of the two mushroom strains on C. orbiculare under greenhouse conditions:

Results recorded in Table (6) show the effect of SMS compost resulted from $P$. florida and $P$. sajor-caju on seed germination and disease incidence of cucumber anthracnose as affected by different mixing doses of SMS.

All treatments used in this experiment seemed to promote germination percentage from 35 (control $2=$ soil $+C$. orbiculare) to $92 \%$ resulted due to using $100 \%$ SMS in case of $P$. florida SMS compost. Although values of germination percentage were lower in case of SMS produced through mushroom production using the strain P. sajor-caju, it promoted from 40 (control 2) to $93 \%$ (100\% SMS). Relative effects of SMS were calculated between each two treatments having the same amount of SMS. The maximum relative increment recorded in case of T7 with $P$. florida SMS which calculated +163 in seed germination, followed by T7 with $P$. sajor-caju $(+132.5)$.

Simultaneously, disease incidence was negatively affected with SMS treatments. The least disease incidence was recorded with T7 with $P$. sajor-caju which recorded negative value that could be explained by saving weak seeds from decline with boost of some antimicrobial substance. Similar results and explanations were expressed by 
several researchers. Litterick et al. (2004) and Zaki et al. (2011) pointed out that the use of compost as soil amendment and their water extracts can provide natural biological control against foliar- and soil-borne diseases and improve plant health. Meanwhile, Dutta et al. (2017) referred the positive effects of SMS compost to nutrients that are essential for plant growth and development, and they are important factors in disease control that may influence disease resistance or tolerance by increasing the capacity of the host plant to restrict invasive pathogens' penetration, development and reproduction.

Table (6): Effect of spent mushroom substrate (SMS) of $P$. florida and $P$. sajorcaju and their soil mixtures on cucumber plants infected with $C$. orbiculare.

\begin{tabular}{|c|c|c|c|c|c|c|}
\hline \multirow{2}{*}{$*$} & \multicolumn{3}{|c|}{ P. florida } & \multicolumn{3}{c|}{ P. sajor-caju } \\
\cline { 2 - 7 } Treatments & $\begin{array}{c}\text { Germination } \\
(\%)\end{array}$ & $\begin{array}{c}\text { Disease } \\
\text { Incidenc } \\
\mathrm{e}(\%)\end{array}$ & $\begin{array}{c}* * \\
\text { Relative } \\
\text { effect of } \\
\text { SMS (\%) }\end{array}$ & $\begin{array}{c}\text { Germinat } \\
\text { ion (\%) }\end{array}$ & $\begin{array}{c}\text { Disease } \\
\text { incidence } \\
(\%)\end{array}$ & $\begin{array}{c}\text { Relative } \\
\text { effect of } \\
\text { SMS (\%) }\end{array}$ \\
\hline T1 & 85.0 & 11.4 & $(+) 21.4$ & 82 & 10.9 & $(+) 24.2$ \\
\hline T2 & 70.0 & 27.1 & -- & 66 & 28.3 & -- \\
\hline T3 & 89.0 & 7.3 & $(+) 20.3$ & 82 & 10.9 & $(+) 13.9$ \\
\hline T4 & 74.0 & 22.9 & -- & 72 & 21.7 & -- \\
\hline T5 & 95.0 & 1.0 & $(+) 3.3$ & 88 & 4.3 & 0.0 \\
\hline T6 & 92.0 & 4.1 & -- & 88 & 4.3 & -- \\
\hline T7 & 92.0 & 4.1 & $(+) 163.0$ & 93 & -1.1 & $(+) 132.5$ \\
\hline T8 & 35.0 & 63.5 & -- & 40 & 56.5 & -- \\
\hline T9 & 96.0 & -- & -- & 92 & & -- \\
\hline
\end{tabular}

$* \mathrm{~T} 1=$ soil $+25 \%$ SMS, $\mathrm{T} 2=$ soil $+25 \%$ SMS $+C$. orbiculare, $\mathrm{T} 3=$ soil $+50 \%$ SMS, T4 $=$ soil $+50 \%$ SMS $+C$. orbiculare $. \mathrm{T} 5=$ soil $+75 \%$ SMS, $\mathrm{T} 6=$ soil + $75 \%$ SMS + C. orbiculare, $\mathrm{T} 7=100 \%$ SMS, T8 $=$ soil $+C$. orbiculare (control 2) and $\mathrm{T} 9=$ soil only (control 1).

** Relative effect of SMS was calculated as increase or decrease values relatively to each individual SMS dose.

Generally, anthracnose is a dangerous plant disease can negatively affect all cucurbitis plants. According to the Agricultural Pesticide Committee (Anon., 2017), no fungicides were recommended in Egypt until 2018 as a foliar application to control anthracnose on cantaloupe because it is commonly edible fresh in Egyptian diets during the summer season and also because of restrictions related to exportation of such an important Agro-commodity.

On the other hand, Abdel-Kawi (1998) produced two important acids for industrial operations during mushroom production process which may add one more value to mushroom production.

Egypt. J. Phytopathol., Vol. 47, No. 2 (2019) 


\section{Conclusion}

From current study and the obtained results, it could be concluded that several strategic targets are achievable through mushroom production process. Obtaining sustainable source of good quality edible protein, safe and beneficial operation of getting rid of some or may be most of seasonal agro-wastes like rice straws and cotton stalks, compost production, production of some important essential substances such as acids and afford safe and environmentally friendly mean of plant disease control.

\section{Ref e r e n e s}

Abdel-Kawi, K.A. 1989. Studies on the Cultivation and Production of Oyster Mushroom Pleurotus spp. M.Sc. Thesis, Fac. Agric., Cairo Univ., 181pp.

Abdel-Kawi, K.A. 1998. Cultivation of Fungal Mushrooms for Production of Citric and Oxalic Acids. Ph.D. Thesis, Fac. Agric., Cairo Univ., 202pp.

Anonymous 1998. Official Methods of Analysis. Assoc. Off. Agric. Chem., $16^{\text {th. }}$ Edition.

Anonymous 2017. Agricultural Pesticide Committee (APC), Official Pesticides Recommendations in Egypt. Al-Ahram Press, Qaliyub, 351pp. ISBN: 978-977302-448-2 (in Arabic).

Arkroyed, W.R. 1966. The nutritive value of indian foods and the planning satisfactory diets, $6^{\text {th }}$ edition, revised by Gopalan, C. and Balasubramanium S.C.I.C.M.R. pp. 257, New Delhi.

Bano, Z. 1976. The Nutritive Value of Mushrooms. Proceedings of First Symposium on Survey and Cultivation of Edible Mushrooms in India R.R.L. Springer, 2:172.

Bano, Z.; Bhagya, S. and Srinivason, K.S. 1981. Essential amino acid and proximate analysis of the mushrooms Pleurotus eous and Pleurotus florida. Mush. Newslet. Trop., 1: 6-10.

Bano, Z. and Rajarathnam, S. 1982. Pleurotus mushroom as a nutritious food. In: Tropical Mushrooms, Biological Nature and Cultivation Methods, eds. S.T. Chang and T.H. Quimio, pp. 363-380, Hong Kong. The Chinese Univ, Press.

Black, C.A.; Evans, D.D.; Ensminger, L.E.; White, J.L.; Clark, F.E. and Dinaure, R.C. 1965. Methods of Soil Analysis. Part II: Chemical and Microbiological Properties. pp. 1367- 1368, Am. Soc. Agron. Inc., Madison, Wisconsin, U.S.A.

Chahal, D.S. 1991. Ligno cellulosic wastes. Biological conversion in bioconversion of waste materials industrial products; ed. Martin, A.M.; pp. 373-400. Elsevier Applied Science London and New-York. 
Chahal, D.S; Moo-Young, M. and Dhillon, O.S. 1979. Bioconversion of wheat straw and wheat straw components into single cell protein. Canad. J. Microbiol., 25: 793-797.

Chen, H.; Ma, Y.; Zhang, W.F.; Ma, T. and Wu, H.X. 2015. Molecular phylogeny of Colletotrichum (Sordariomycetes: Glomerellaceae) inferred from multiple gene sequences. Genet. Mol. Res., 14(4): 13649-13662.

Chen, J.T. and Huang, J.W. 2011. Antimicrobial activity of edible mushroom culture filtrates on plant pathogen. Plant Pathol. Bull., 19:261-270.

Conrath, U. 2006. Systemic acquired resistance. Plant Signal Behav., 1: 179-184.

Domasch, K.H.; Gams, W. and Anderson, T.H. 1980. Compendium of Soil Fungi, 1:1-680.

Dubois, M.; Gilles, K.A.; Hamilton, J.K.; Robon, P.A. and Smith, F. 1956. Colorimetic method for determination of sugar and related substances. Anal. Chem., 28: 336-350.

Dutta, S.; Ghosh, P.P.; Ghorai, A.K.; De Roy, M. and Das, S. 2017. Micronutrients and plant disease suppression. Fert. and Environ. News, 9: 59-67.

El-Wakil, A.A. and El-Zefzaf, H.M. 2001. A new record of cantaloupe anthracnose in Egypt. Egypt. J. Phytopathol., 29(2): 119-120.

Estrella, F.S.; Bustamante, M.A.; Moral, R.; Vargas-Garrcia, M.C.; Lopez, M.J. and Moreno, J. 2012. In Vitro control of Fusarium wilt using Agroindustrial subproducts-based composts. J. Plant Pathol., 94(1): 59-70.

Garcha, H.S. 1981. Spawn production of Pleurotus spp. Mush. Newslet. Trop., 2(3): 7-9.

Gregori, A.; Mirjan, S. and Jure, P. 2007. Cultivation techniques and medicinal properties of Pleurotus spp. Food Technol. Biotechnol., 45: 238-249.

Horwitz, W. 1980. Offical Methods of Analysis, "13 $3^{\text {th. }}$ ed., Association of Official Analytic Chemists, Washington, USA.

Jwanny, E.; Rashad, M. and Abdu, M. 1995. Solid state fermentation of agricultural wastes into food through Pleurotus cultivations. Appl. Biochemist. and Biotechnol.. Part A. Enzyme Engin. and Biotechnol., 50(1): 71-78.

Kalberer, P.P. and Kunsch, U. 1974. Amino acid compostion of oyster mushroom Pleurotus ostreatus, Lebensm, Wiss. U. Technol., 7: 242-244.

Khalil, A.A.; El-Abbasi, I.H. and El-Wakil, A.A. 2018. Molecular technology confirms identification of cantaloupe anthracnose caused by Colletotrichum sp. Egypt. J. Phytopathol., 46(1): 37-48.

Egypt. J. Phytopathol., Vol. 47, No. 2 (2019) 
Khan, S.M.; Nawas, A.; Ali, M.A.; Ahmed, T.; Khan, N.A. and Rehman, A. 2012. Response of oyster mushroom on different agricultural wastes of southern Punjab. Pak. J. Agric. Sci., 48: 127-130.

Khanna, P. and Garcha, H.S. 1982. Utilization of paddy straw for the cultivation of Pleurotus spp. Mushroom Newsletter for the Tropics, 2(3): 5-9.

Lin, K.W.; Ladish, M.R.; Voloch, M.; Patterson, J.A. and Nolle, C.H. 1985. Effect of pre-treatments and fermentation on pore size in cellulose materials. Biotechnol. Bioeng., 27: 1427-1433.

Litterick, A.M.; Harrier, L.; Wallace, P.; Watson, C.A. and Wood, M. 2004. The role of uncomposted materials, composts, manures and compost extracts in reducing pest and disease incidence and severity in sustainable temperate agriculture and horticulture crop production-a Review. Critical Rev. Plant Sci., 23:453-479.

Montgomery, R. 1961. Further studies of the phenolsulphuric acid reagent for carbohydrates. Biochem. Biophys. Acta., 84: 591-593.

Mueller, J.C. and Gawley, J.R. 1983. Cultivation of phoenix mushrooms on pulp mill sludges. Mushroom Newsletter for the Tropics, 4(1): 3-12.

Rai, R.D.; Saxena, S.; Upadhyay, R.C. and Shoi, H.S. 1988. Comparative nutritional value of various Pleurotus species grown under identical conditions. Mushroom. J. Tropics 8: 93-98.

Randhir, S.; Singh, D.; Yadav, K. and Singh, R. 1999. Use of agro-byproducts for spawn production of edible mushroom P.sajor-caju. Environ. \& Ecol., 17(1): 199-206.

Ravinder, K.; Chandrashekara, C.; Arunkumar, R. and Bhatt, J.C. 2012. Performance of four species of oyster mushroom (Pleurotus spp.) on various agro-wastes and supplements in north-western Himalaya. J. Mycol. Plant Pathol., 42: 326-331.

Sangpueak, R.; Phansak, P. and Buensanteai, N. 2017. Morphological and molecular identification of Colletotrichum species associated with cassava anthracnose in Thailand. J. of Phytopathol., 166 (2): 129-142.

Sathyaprabha, G.; Pannneerselvam, A. and Kumaravel, S. 2011. Cultivation of Pleurotus platypus and Pleurotus eous in different agricultural waste substrates. J. Pharm. Res., 4: 2543-2544.

Singh, M. and Grienseven, L.V. 2000. Biodegradation of lignocellulosic wastes through cultivation of $P$. sajor-caju (Science and Cultivation of Edible Fungi for the $15^{\text {th }}$ Proceeding International Congress on Maastricht, Netherlands., 15-19 May, 517-521. 
Sivaprakasam, K.S. 1983. Nutritive value of sporophores of Pleurotus sajor-caju. Indian Mush. Sci. \& Cultiv. Technol. of Edible Fungi. Eds. T.N. and B.M. Kapur, pp. 197-209.

Stanley, H.O.; Umolo, E.A. and Stanley, C.N. 2011. Cultivation of oyster mushroom (Pleurotus pulmoarius) on amended corn cobs substrate. Agric. Biol. J. N. Amer., 2: $1239-1243$.

Syed, A.A.; Kadam, J.A.; Mane, V.P.; Patil, S.S.; Baig, M.M.V. 2009. Biological efficiency and nutritional contents of Pleurotus florida (Mont.) Singer cultivated on different Agro-wastes, Natural Science, 7(1): 44-48.

Tanaka M.; Robinon, C.V. and Moo-Young, M. 1985. Chemical and enzymes pretreatment of corn stover to produced soluble fermentation substrates. Biotechnol. Bioeng., 27: 362-368.

Vallad, G.E. and Goodman, R.M. 2004. Systemic acquired resistance and induced systemic resistance in conventional agriculture. Crop Sci., 44: 1920-1934.

Walker, J.; Nikandrow, A. and Miller, G.D. 1991. Species of Colletotrichum on Xanthium (Asteraceae) with comments on some taxonomic and nomenclature problems in Colletotrichum. Mycol. Res., 95: 1175-1193.

Weir, B.; Damm, U. and Johnston, P.R. 2012. The Colletotrichum gloeosporioides species complex. Stud. Mycol., 74: 113-180.

Zaki, K.I.; Zayed, M.S. and Abd-alraheim, A.M. 2011. Foliar application of composttea and bicarbonate salts for controlling powdery mildew disease on squash plants in North Sinai. Egypt. J. Phtyopathol., 39(1): 201-220.

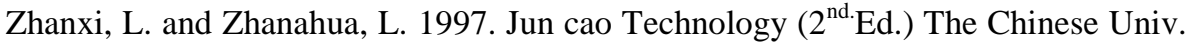
Press Hong Kong, pp.10-15.

Corresponding author: Khalil, A.A.

E-mail: amalkhali1000@gmail.com

(Received 10/02/2019;

in revised form 24/02/2019)

Egypt. J. Phytopathol., Vol. 47, No. 2 (2019) 


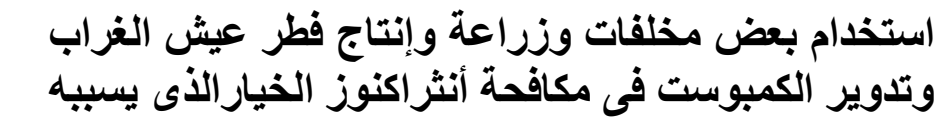

Colletotrichum orbiculare

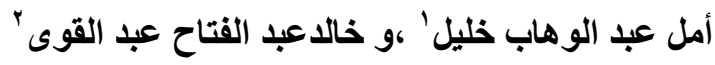

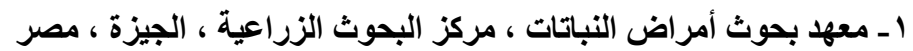

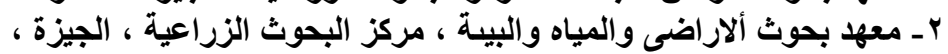

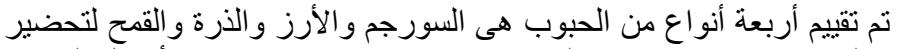

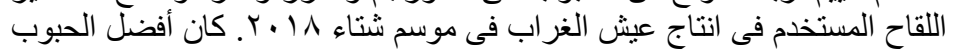

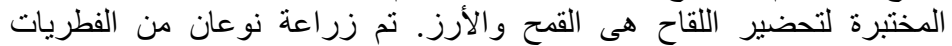

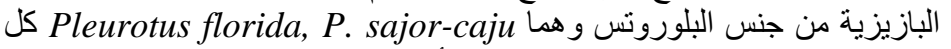

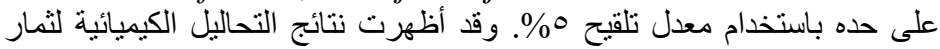
السلالة P. sajor-caju

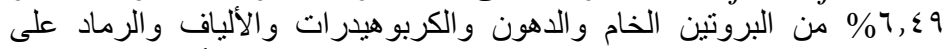

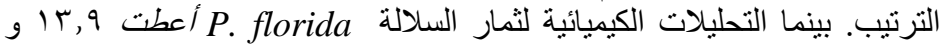

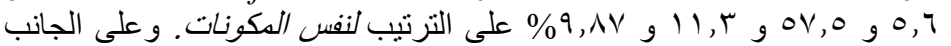

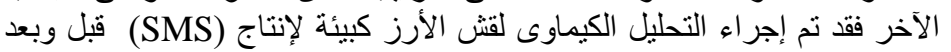

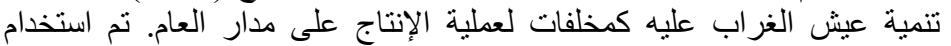

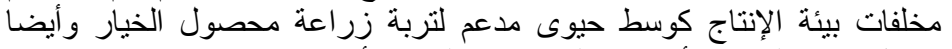

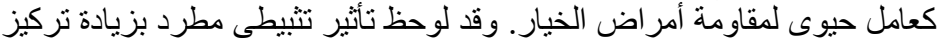

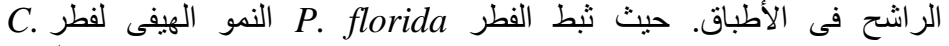
orbiculare

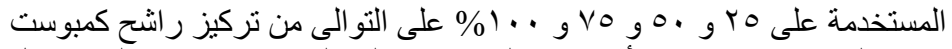
عيش الغراب. وقد تفوق تأثئير مستخلص ثمار السلالة

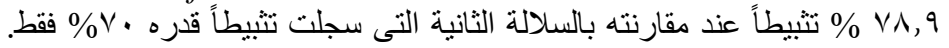

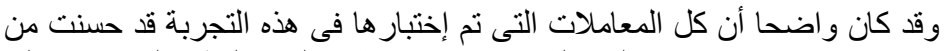

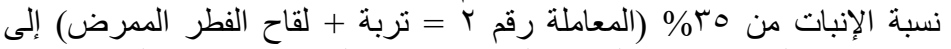

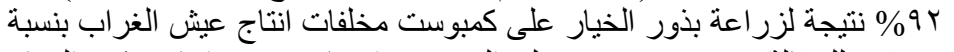

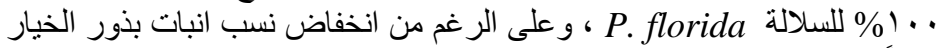

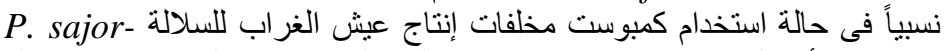
caju

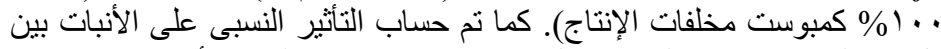

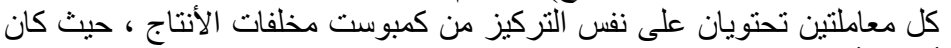

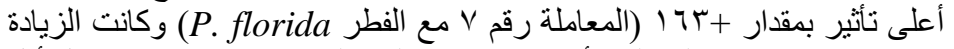

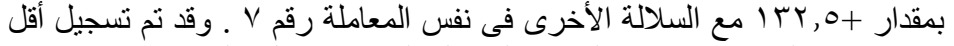

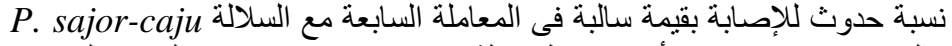

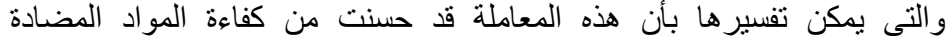

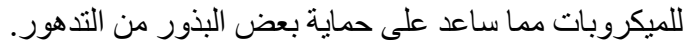

